\title{
Covid-19 Pandemi Sürecinde Bir Köyde Yaşayan Altı Yaş Çocukların Oyun Yaşantılari*
}

\author{
Play Experiences of Six-Year-Old Children Living in a Village During the Covid-19 Pandemic
}

\author{
Aylin SOP* (D), Şeyma DEMİRGIRAN (iD
}

\begin{abstract}
ÖZ
Amaç: Covid-19 pandemi süreci ile birlikte alınan önlemler doğrultusundaki kısıtlamalar çocukların hayatlarına yeni bir gerçeklik getirmiştir. Bu durum çocukların okul dışı ortamlarda oyun oynamalarına neden olmuş, oyun ortamları ve oyun arkadaşları farklılaştırıp daha az aktiviteye dayalı zamanlar geçirmelerine neden olmuştur. Okul öncesi dönem çocuklarının en önemli uğraşı oyun davranışları da bu doğrultuda değişiklikler göstermiştir. Mevcut çalışma ile birlikte bir köyde yaşayan okul öncesi dönem çocuklarının Covid-19 Pandemi sürecinde değişen oyun yaşantıları belirlenmeye çalışılmıştır.

Yöntem ve Araçlar: Çalışmada nitel araştırma yöntemlerinden fenomenoloji tasarımından yararlanılmıştır. Çalışma grubu, Van ilinde MEB’a bağlı bir köy okuluna devam eden 6 yaşındaki 10 çocuktan oluşmaktadır. Araştırmanın verileri uzman görüşü alınarak hazırlanan iki bölümden oluşan yarı yapılandırılmış görüşme formu ile elde edilmiştir. Veriler içerik analizi tekniği kullanılarak çözümlenmiş, kod ve kategoriler oluşturularak yorumlanmıștır.

Sonuçlar: Okul öncesi dönem çocukları pandemi sürecinde harekete dayalı oyunları tercih ettiklerini ve dışarı alanda, arkadaş ortamında her zaman oyun oynadıklarını ifade etmişler, ifadelerini çizdikleri resimler ile desteklemişlerdir. Pandemi sürecinin çocuklarının oyun algılarını olumsuz etkilemediği, kaygıya sebep olmadığı onların her zaman severek oyun oynamaya devam ettiklerini ancak arkadaş ortamlarına ve okula özlem duyduğunu göstermektedir. Araştırma sonuçları tartışılarak öneriler sunulmuştur.

Anahtar Kelimeler: COVID-19 pandemisi, Oyun, Okul öncesi dönem

\section{ABSTRACT}

Purpose: The restrictions imposed in line with the measures taken with the Covid-19 pandemic have brought a new reality to the lives of children. Children have started to play outside the school, differentiate their play environments and playmates and spend less activity-based time. Correspondingly, play behaviors which are preschool children's most important engagement have also changed. With the current study, it was attempted to determine pre-school children's experiences of the play during the Covid-19 pandemic.

Method and Materials: The current study employed the phenomenological design, one of the qualitative research methods. The study group is comprised of 10 children aged 6 years attending a village school affiliated to the Ministry of National Education in the city of Van. The data of the study were collected by using a semi-structured interview form consisting of two parts and prepared by seeking expert opinion. The collected data were analyzed through the content analysis technique and then interpreted by creating codes and categories.

Results: The pre-school children stated that they preferred active plays during the pandemic and that they always played games outside with their friends and they supported their statements with the pictures they drew. The results showed that the pandemic process did not negatively affect children's perceptions of play and did not cause anxiety, that children always continued to play games but that they missed their friends and school. In light of the results of the study, some suggestions were made.
\end{abstract}

Keywords: COVID-19 pandemic, Play, Preschool period.

* Mevcut çalışma 7. Uluslararası Okul Öncesi Eğitim Kongresi’nde (IECEC-UOEK 2021) sözlü bildiri olarak kabul edilmiştir.

** Burdur Mehmet Akif Ersoy Üniversitesi Eğitim Fakültesi Temel Eğitim Bölümü

Sorumlu Yazar/Correspondence Author: Aylin SOP

E-posta/E-mail: adursun@mehmetakif.edu.tr 


\section{GİRIŞ}

COVID-19 Pandemisi ile birlikte tüm Dünyada olduğu gibi ülkemizde de salgının yayılımının önlenmesi amacıyla bazı kısıtlamalar uygulanmış bu bağlamda sokağa çıkma kısıtlamaları, okulların kapanması ve sosyal etkileşimini minimum düzeye indirmeye yönelik uygulamalar yapılmıştır. Bu durum insan sağllğı başta olmak üzere eğitim, ekonomi, psikoloji ve sosyal hayatı derinlemesine etkilemiştir. En çok etkilenen gruplardan biri de çocuklardır. Okulların kapanması ile birlikte çocukların sosyal ortamları kısıtlanmış, örgün eğitime zorunlu olarak ara verilmiş ve uzaktan eğitime geçilmiştir (Can, 2020). Okulların kapanması ve sokağa çıkma kısıtlamaları çocukların hayatlarında yeni başlangıçlara sebep olmuştur. Okuldan ve arkadaş ortamlarından yoksun kalan çocukların oyun oynama süreçleri de değişiklik göstermiştir. Küçük çocukların oyuna katılma konusunda doğal bir eğilimi vardır, ancak oyuna bakış açısı aynı zamanda sosyal ve fiziksel ortamlara da bağlıdır. Oyun alanlarında oynanan oyunlar çocukların yaratıcıllğııı ve bağımsızlığını sağlamakta sosyalleşmesini geliştirmekte, çocukların ilgisine göre fazla enerjilerini boşaltmalarını sağlamaktadır. Oyun alanları çocukların fiziksel, sosyal ve bilişsel olarak desteklendiği yaratıcılıklarını kullandığı alanlar olmasından dolayı önemlidir (Ünal, 2009).

Oyun, çocuğun var olduğu her yerde olan evrensel bir kavramdır. Oyunun türü, ismi, kullanılan araç gereçler kültürden kültüre değişiklik gösterse de oyun çocuğun olduğu her yerde her zaman var olacaktır (Koçyiğit, Tuğluk, ve Kök, 2007). Oyun hakkında eski zamanlardan beri oldukça fazla tanımlar yapılmış görüşler sunulmuştur. Piaget' e göre oyun, bir uyumdur. Gross' a göre oyun bir pratiktir. Montessori' ye göre oyun, çocuğun işidir. Lazarus' a göre oyun, kendiliğinden ortaya çıkan, hedefi olmayan, mutluluk getiren bir aktivitedir. Montaigne’e göre (1533-1592) oyun çocukların en gerçek uğraşıdır. Tanımların tamamındaki ortak nokta oyunun çocuk hayatındaki yerinin çok önemli olduğudur (Burgaz Uskan ve Bozkuş, 2019). Oyunda küçük çocuklar keşfetmek, denemek ve deneyimlerini başkalarıyla paylaşmak için içsel olarak motive olurlar ve tüm duyularını, sosyal ve bilişsel kapasitelerini kullanırlar (Singer vd., 2013). Çocukların tüm gelişim alanına sağlamış olduğu katkı ile birlikte ruhsal doyumunu sağladığı, eğlenceli bir etkinlik olan oyun kişilik gelişimine katkı sağlayarak kişinin kendisini iade etmesinin en kolay yoludur. Bilgi ve becerinin, kavram ve cisimlerin, kuralların öğretildiği eğitimin bir parçasıdır (Özer, Gürkan ve Ramazanoğlu, 2006). Okul öncesi dönemde oyunlarda arkadaşlarla geçirilen zamandaki artış ile birlikte sosyal davranış ve akran ilişkileri, problem çözme becerisi ve işbirliği yeteneği gibi sosyal becerilerin geliştirdiği görülmektedir. Oyun becerilerinin gelişmesi sosyal beceriler için belirleyici temel unsur olarak görülmektedir (Gülay, 2009).

Çocuk oyunları üzerine yapılan çalışmalarda Güven (2018) oyunun eğlendiren bir etkinlik olarak tanımlandığını, oyun oynamanın çocukta mutluluk, eğlence sevinç ve heyecan hali yarattı̆̆ını ifade etmiştir. Pilten ve Pilten (2013) çocukların, her hangi bir aktivitenin oyun olup olmadığına karar vermede kullandıkları temel ölçütün eğlence olduğu ve oyun ve oyuncak tercihleri cinsiyete ilişkin kalıp yargılarla ve yaşla birlikte şekillenmekte olduğu sonucunu bulmuştur. Erbay ve Saltalı (2012) çocukların okul dışı zamanlarının çoğunu oyun oynayarak ve televizyon izleyerek geçirdikleri, oyunlarını en çok arkadaşlarıyla ve anne-babalarıyla oynadıkları, ev içerisinde en çok kendi odaları ve salonda oyun oynadıkları bulmuş, annelerin çocuklarla oyun oynama konusunda ise en çok yorgunluk konusunda sıkıntı yaşadığı sonucu elde etmiştir. Tuğrul vd.(2014) arkadaşlarla oynanan, fiziksel aktiviteye dayalı dış mekân oyunlarından, teknolojik ürünlerle iç mekânlarda oynanan oyunlara doğru değişim yaşandığ 1 tespit edilmişlerdir. Yapılan araştırmalar çocukların oyun algılarına ilişkin önemli kanıtlar ortaya koysa da Covid-19 Pandemi sürecinde özel olarak çocukların oyuna kavramına ilişkin algılarını inceleyen çalışmaya rastlanmamıştır. $\mathrm{Bu}$ nedenle bu çalışmanın Pandemi gibi olağan dışı durumların çocukların değişen oyun kavramı üzerine etkilerini belirlemeye yönelik olması okul öncesi alanında alan yazına katkı sağlayacağı için önemli görülmektedir. Bu düşünceden hareketle bu çalışma ile Covid-19 Pandemi sürecinde okul öncesi dönem çocuklarının oyun yaşantıları incelenmiştir. Araştırma soruları şu şekilde belirlenmiştir:

Covid-19 Pandemi sürecinde;

1. Çocukların en sevdiği oyunlar ve en çok oynadığı oyunlar nelerdir?

2. Çocukların oyun oynarken hissettikleri duyguları nasıldır?

3. Çocukların oyun süreçlerine (zaman, mekan ve kişi) ilişkin algıları nasıldır?

4. Çocukların okulda ve evde oynadığı oyunları farklılaşmakta mıdır?

5. Çocukların öğrendiği yeni oyunlar nelerdir? 


\section{YÖNTEM}

\section{Araştırma Deseni}

Araştırmada bir köyde yaşayan çocukların Covid - 19 Pandemi sürecinde okulların kapanması ve sokağa çıkma kısıtlamalarınedeniyleoyun yaşantıları değiştiği düşünüldüğünden nitelaraştırma yöntemlerinden Fenomenoloji deseninden yararlanılmıştır. Nitel araştırmalarda veriler görüşme, gözlem ve doküman analizi gibi yöntemlerle bireylerin yaşadığı gerçek ortamda doğrudan elde edilerek derinlemesine betimlenir (Büyüköztürk, Çakmak, Akgün, Karadeniz, Demirel, 2014). Fenomenoloji, çeşitli hallerde günlük hayatta sıklıkla karşımızda çıkabilen farkında olduğumuz ama derinlemesine ve ayrıntılı bilgi sahibi olmadığımız olgulara odaklanır (Yıldırım ve Şimşek, 2016). Birkaç kişinin bir fenomen ya da bir kavramla ilgili yaşanmış deneyimlerinin ortak anlamını tanımlamada kullanılan bir çalışma türüdür (Creswell, 2013).

\section{Katılımcılar}

Araştırmanın verileri 2020-2021 eğitim-öğretim yılında Van ili Gürpınar ilçesinde Milli Eğitim Bakanlığına bağlı bir köy okulunun anasınıfındaki 10 çocuk oluşturmaktadır. Araştırma kapsamında görüşme yapılan okul öncesi çocuklarının kişisel bilgilerine göre dağılım Tablo l'de sunulmuştur.

Tablo 1: Katılımcıların Demografik Özellikleri

$\begin{array}{ccccc}\text { Katılımcılar } & \text { Cinsiyet } & \text { Yaş } & \text { Kardeş Sayısı } & \text { Okul Öncesi Eğitim } \\ \text { Alma Süresi }\end{array}$

Tablo 1 'de görüldüğü üzere 5’i kız; 5’i erkek olmak üzere 10 çocuk araştırmaya katılmıştır. Çocuklardan 9’u 6 yaşında; 1'i 7 yaşındadır. Çocukların kardeş sayısında bakıldığında 1'i 1 kardeş; 3'ü 2 kardeş; 4'ü 3 kardeş; 2'si 4 kardeş oldukları belirlenmiştir. Çocukların okul öncesi eğitim alma süreleri 1-2 yıl aralığında değişmektedir.

\section{Veri Toplama Araçları}

Araştırmada veri toplama aracı olarak araştırmacı tarafından oluşturulan yarı yapılandırılmış görüşme formu ve resim çizdirme tekniği uygulanmıştır. Araştırma verilerini elde etmek için yarı-yapılandırılmış görüşme formunda yer alan görüşme sorularına Tablo 2'de yer verilmiştir:

Tablo 2: Görüşme Soruları

\begin{tabular}{|c|c|}
\hline Oyun Algılarına ilişkin görüşme soruları & Resim Sonrası Görüşme Soruları \\
\hline 1.En çok hangi oyunları oynamayı seversin? & 1.Bu resimdeki oyunu bana anlatır misın? Nasıl oynanıyor? \\
\hline 2.En sevdiğin oyun hangisi? & 2. Resmindeki oyunu en çok kimlerle oynuyorsun? \\
\hline 3.Bana nasıl oynandığını anlatır mısın? & 3. Resmindeki oyun nerede oynanıyor? \\
\hline \multicolumn{2}{|l|}{ 4.Oyun oynarken kendini nasıl hissediyorsun? } \\
\hline \multicolumn{2}{|l|}{ 5.En çok ne zaman oyun oynamayı seversin? } \\
\hline \multicolumn{2}{|l|}{$\begin{array}{l}\text { 6.Genelde nerede oyun oynuyorsun? Başka nerelerde oyun } \\
\text { oynamak isterdin? }\end{array}$} \\
\hline \multicolumn{2}{|l|}{ 7.Oyun arkadaşların kim? Kimlerle oyun oynamayı seviyorsun? } \\
\hline \multicolumn{2}{|l|}{$\begin{array}{l}\text { 8. Okulda oynadığın oyunlar nasıl, evde oynadığın oyunlar } \\
\text { nasıl? Birbirinden farklı mı? }\end{array}$} \\
\hline \multicolumn{2}{|l|}{ 9.Okulların kapanmasıyla öğrendiğin yeni oyunlar nelerdir? } \\
\hline 10.Bana en sevdiğin oyunu çizer misin? & \\
\hline
\end{tabular}


Ayrıca bu araştırmada, araştırmacı tarafından hazırlanan "Kişisel Bilgi Formu" kullanılmıştır. Kişisel Bilgi Formuna çocuğun cinsiyeti, yaşı, kardeş sayısı ve okul öncesi eğitim alma süresi gibi bilgiler kaydedilmiştir.

\section{Verilerin Toplanması ve Analizi}

Görüşme formundan elde edilen veriler, çocukların çizmiş olduğu resimler ve resimler ile ilgili yapılan görüşmeler sonucunda elde edilen veriler içerik analizi tekniği ile çözümlenmiştir. İçerik analizi, belirli kurallara dayalı kodlamalarla bir metnin bazı sözcüklerinin daha küçük içerik kategorileri ile özetlendiği sistematik, yinelenebilir bir teknik olarak tanımlanır (Büyüköztürk, Çakmak, Akgün, Karadeniz, Demirel, 2014). Bu araştırmaya katılan 10 çocuğun Covid-19 Pandemi sürecinde değişen oyun yaşantılarını belirlemek amacıyla ilk görüşmede en sevdiğin oyun, nerede oynadığı ne zaman oynadığı gibi oyunlarına etki eden faktörler ile ilgili sorular sorulmuştur. Ebeveynlerinden bilgilendirilmiş onam formu ile izinler alınarak ebeveynleri eşliğinde çocuklarla canlı görüşmeler sağlanarak iletişime geçilmiştir. İlk görüşme yapıldıktan sonra çocuklardan en sevdiği oyunun resmini çizmeleri istenmiştir. Yapılan resimler ışığında okul öncesi dönem çocuklarının oyun kavramına ilişkin algıları tekrar yapılan görüşmeler ile belirlenmeye çalışılmıştır. Veriler Nisan 2021'de toplanmıştır. Araştırmanın her alt problemi için belirlenen temalar altında kodlar oluşturulmuş ve araştırmaya katılan çocuklar Çocuk 1 (Ç1), Çocuk 2 (Ç2), Çocuk 3 (Ç3) vb. şekilde isimlendirilmiştir. Araştırmacı tarafından yapılan yorumların ve çalışma bulgularının inandırıcılığını sağlamak amacıyla çocukların ifadelerinden birebir alıntıya yer verilmiştir.

\section{Araştırmanın Geçerliği ve Güvenirliği}

Nitel araştırmalarda güvenirliği sağlamak önemli ölçütlerden biridir. Bu araştırmada da inandırıcılığı sağlamak için bazı hususlara dikkat edilmiştir. Soru maddelerinin geçerliliği iki uzman görüşüne göre belirlenmiştir. Araştırmacı tarafından görüntü kaydı alınarak görüşmeler yapılmıştır. Görüşmelerin dökümü eksiksiz bir şekilde bilgisayar ortamına aktarılmıştır. Dosyadaki cevaplar analiz edilerek kod ve kategoriler ilgili kavramları kapsayacak kadar geniş, konuyla ilgisiz kavramları dışarıda bırakacak kadar dar kapsamda oluşturulmuştur. Ayrıca çocuklardan elde edilen veriler nitel araştırma yöntemleri konusunda deneyimli bir başka öğretim üyesi tarafından da kod kategori oluşturmada görüş alınmıştır. Araştırmanın iç güvenirliğini arttırmak amacıyla bulgular değiştirilmeden alıntılar yapılarak sunulmuştur. Araştırmada iki farklı görüşme formu kullanılmıştır. Bir nitel veriyi başka bir nitel veri ile desteklenerek daha güvenilir sonuçlar elde edilmiştir. Ayrıca oyun algısına yönelik birincil veri kaynağı olan görüşme kayıtlarından elde edilen bulgular ikincil nitel veri kaynakları olan konu ile ilgili resim çizdirme ve resim sonrası yapılan görüşmelerinden elde edilen bulgularla desteklenmiştir. Böylece araştırmada veri çeşitlemesine gidilerek daha güçlü yorumlamalar yapılmıştır.

\section{BULGULAR}

Bu bölümde analizler sonucunda elde edilen bulgu ve yorumlara yer verilmiştir.

\section{Birinci araştırma sorusuna ilişkin bulgular}

Çocuklara 'en çok hangi oyunları oynuyorsun?” ve "en sevdiğin oyunu bana çizebilir misin?” soruları sorulmuş, toplanan görüşler kategoriler halinde sunulmuştur. Çocukların en çok oynadığı oyunlara Tablo 3'te ve resim örneğine Şekil 1'de yer verilmiştir.

Tablo 3: Çocukların En Çok Oynadığı Oyunlar

\begin{tabular}{lll} 
Kategoriler & Kodlar & $\mathrm{n}$ \\
\multirow{3}{*}{ Harekete dayalı oyunlar } & Saklambaç oyunu & 5 \\
& Yakalama/parkur oyunu & 4 \\
& Top oynama, Körebe, tren oyunu & $1,1,1$ \\
\hline \multirow{2}{*}{ Araçlı oyunlar } & Bisiklet sürme & 2 \\
& Kilıç oyunu, minder, oyuncak, salıncak & $1,1,1$, \\
\hline \multirow{2}{*}{ Sembolik oyunlar } & Bebeklerle oyun & 3 \\
& Evcilik oyunu & 2 \\
\hline
\end{tabular}




\begin{tabular}{lll}
\hline \multirow{2}{*}{ Birlikte oyunlar } & Kardeş ile oyun & 3 \\
& Arkadaş ile oyun & 1 \\
\hline Yapı inşa oyunları & İşaat-çamur oyunu, su oyunları & 1,1 \\
\hline Müzikli oyunlar & Heykel oyunu, kutu kutu pense & 1,1 \\
\hline Hayvanlarla vakit geçirme & Kuş & 1 \\
\hline Dijital oyunlar & Telefon-internet oyunları & 1 \\
\hline Zekâ oyunları & Satranç oyunu & 1 \\
\hline Toplam & & 34 \\
\hline
\end{tabular}

Tablo 3 incelendiğinde çalışma grubunda yer alan 10 çocuğa en çok hangi oyunları oynadıkları sorulmuş elde edilen 34 cevap 9 kategori altında toplanmıştır. Katılımcıların cevaplarına bakıldığında; hareketli oyunlar $(\mathrm{n}=12)$; araçlı oyunlar $(\mathrm{n}=6)$; sembolik oyunlar $(\mathrm{n}=5)$ en çok görüş bildirilen kategorilerdir. Bu bulguyu destekler nitelikte çocukların ifadesine aşağıda yer verilmiştir:

"Saklambaç başka yakalamacılık, kılıçcllık oynuyorum, resim yapıyorum, bebeklerimle oynuyorum, dışarda Sümeyye arkadaşımla oynuyorum, başka minderle oynuyorum.” (Ç1)

"Telefon oynuyoruz, saklambaç, yakalamaca, gratbill ev oyunları telefonda izliyoruz internette" (Ç6)

"Heykel her gün arkadaşlarımla şarkı açıp burada oynuyoruz." (Ç7)

Çocuklara "En sevdiğin oyun hangisi?" sorusu sorulmuş, toplanan görüşler analiz edilerek kategoriler oluşturulmuştur. Kategorilere ilişkin bilgiler söylenme sıklı̆̆ına göre Tablo 4’de sunulmuştur.

Tablo 4: Çocukların En Çok Sevdiği Oyunlar

\begin{tabular}{lcc} 
Kategoriler & Kodlar & $\mathrm{n}$ \\
Hareketli oyunlar & Saklambaç oyunu & 3 \\
& Yakalamaca oyunu & 2 \\
\hline Araçlı oyunlar & Koşu yarışı, Körebe oyunu, top oynama & $1,1,1$ \\
\hline Hayvanlarla vakit geçirme & Bisiklet sürme & 2 \\
\hline Müzik oyunları & Kuş, kuzu & 1,1 \\
\hline Sembolik oyunlar & Heykel oyunu & 1 \\
\hline Toplam & Bebek oyunları & 14 \\
\hline
\end{tabular}

Tablo 4 incelendiğinde çalışma grubunda yer alan 10 çocuğa en çok sevdiği oyun sorulmuş 5 kategoride altında toplam 14 cevap alınmıştır. en çok sevilen oyunlar söylenme sıklığına göre sırası ile hareketli oyunlar $(\mathrm{n}=8)$; araçlı oyunlar ( $n=2)$; hayvanlarla vakit geçirme $(n=2)$; müzik oyunları $(n=1)$; sembolik oyunlar $(n=1)$ olduğu görülmektedir. bu bulguyu destekler nitelikte bir çocuğun ifadesine aşağıda yer verilmiştir:

"Saklambaç, körebe, ebelemece, koşu yarışı." (Ç2)

"Bebek makyajı oyunu seviyorum."(Ç8)

Çocuklara en sevdiğin oyunu "Bana nasıl oynanıyor çizerek anlatır mısın?" sorusu sorulmuş ve çocukların resim çizmeleri istenmiştir. Çocukların çizimlerinden elde edilen veriler kategoriler halinde sunulmuştur. Çocuklar hareketli oyunlar $(n=4)$; hayvanlarla vakit geçirme $(n=2)$; araçlı oyunlar $(n=1)$; dijital oyunlar $(n=1)$; müzikli oyunlar $(\mathrm{n}=1)$; yapı inşa oyunları $(\mathrm{n}=1)$ çizmişlerdir. Ç1 hareketli oyun kategorisinden en çok saklambaç oyununu sevdiğini " "Bir tane ağaç iki tane ağaç çizdim iki tanede erkek çocuk çizdim. Bir tanesini ağacın oraya sakladım bir tanesi gitti onu buldu oyun bitti. Bir kişi sayıyo ondan sonrada çocuk arıyo arıyo ondan sonrada bir tane çocuk saklanmıştı onu ebeledi." olarak ifade etmiş ve Şekil l'deki şekilde resmetmiştir: 


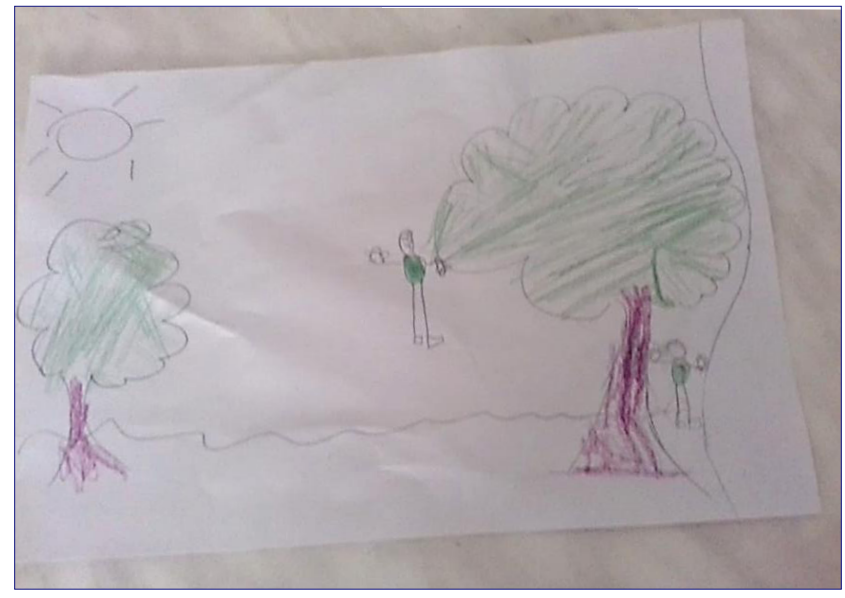

Şekil 1. Saklambaç oyunu

Hayvanlarla vakit geçirmeyi sevdiği söyleyen iki çocuğun ifadesine aşağıda yer verilmiştir:

"elime konuyor onunla oynuyorum böyle yere bırakıyoruz koşuyor sonra boynuma konuyor sonrada eline geliyor her yerime geliyor."(Ç4)

"Bizim boncuk da çok tatl biliyor musun? Benim gibi çok bebek onunla oyun oynuyoruz acıktığında ben hep ot veriyorum. Ne zaman acıktığinda ot veriyorum. Tabi ki hapşsurunca ben yani o hapşurduğunda anliyorum, çünkü ben hayvanların dilinden anliyorum çünkü. Annem dedi ki boncuğun hislerini anliyorum. Acıktığında böyle ağzın mutsuz ediyor. Keçi gibi möö der. Onun koyun gibi möö demesi gerekiyordu nasıl dedi ben de şaşırdım." (Ç5)

Yapı inşa oyunları temasını destekler nitelikte bir çocuğun ifadesine aşağıda yer verilmiştir:

"Abimle beraber yuvarlak yapıyoruz suyu döküyoruz çimentoyla beraber ondan sonra karıştırıyoruz sonra evi yapıyoruz."(Ç10)

Dijital oyunlar temasını destekler nitelikte bir çocuğun ifadesine aşağıda yer verilmiştir:

"Bir tane bebek var bebek geliyor mesela makyaj istiyor makyaj yapıyorsun, elbise istiyor elbise giydiriyorsun, partiye gidiyor, müzik filan söylüyor eve geliyor yüzü siliyor böyle. Tablette ve telefonda. Bizde vardı bu oyunlarda ablam sildi."(Ç8)

\section{İkinci araştırma sorusuna ilişkin bulgular}

Çocuklara 'Oyun oynarken kendini nasıl hissediyorsun?' diye sorusu sorulmuştur. Alınan 12 cevap 4 kategori altında toplanmıştır. Kategorilere ilişkin bulgulara Tablo 5’te yer verilmiştir.

Tablo 5: Çocukların Oyun Sırasındaki Duygularına Yönelik Temalar

\begin{tabular}{ccc}
\hline Kategoriler & $\mathrm{n}$ \\
\hline Mutlu & 10 \\
Heyecanlı & 2 \\
Yorgun, Mutsuz & 1,1 \\
Toplam & 14 \\
\hline
\end{tabular}

Tablo 5 incelendiğinde çalışmaya katılan 10 çocuktan oyun oynarken kendisini nasıl hissettiğine yönelik 14 cevap alınmıştır. Çocuklar oyun esnasında genellikle mutlu $(n=10)$ ve heyecanlı $(n=2)$ olduklarını; iki çocuk ise kendimi mutsuz ve yorgun hissettiğini ifade etmiştir. Mutsuz temasında yer alan bir çocuğun ifadesine aşağıda yer verilmiştir:

"Mutsuz çünkü barbienin kafası kırıldı böyle açıllyor. Birde boncuk ailesinin yanına gitti mutsuz hissediyorum kesilseydi ben ă̆lardım."(Ç5) 


\section{Üçüncü araştırma sorusuna ilişkin bulgular}

Çocukların oyun süreçlerine ilişkin olarak üç ayrı soru sorulmuştur. Oyunu ne zaman, nerede ve kimlerle oynadığına ilişkin cevaplar analizler edilerek tablo halinde sunulmuştur. Ayrıca çocuklardan oyun arkadaşlarıyla nerede oynadıklarına dair resim çizmeleri istenmiş ve resimler şekil 2 ve şekil 3’te gösterilmiştir. Kategoriler ilişkin bilgiler sırayla Tablo 6’da yer verilmiştir.

Tablo 6: Çocukların Oyun zamanı, oyun mekanı ve oyun oynadığı kişiler

\begin{tabular}{|c|c|c|c|c|c|}
\hline \multirow[b]{2}{*}{ Kategoriler } & \multicolumn{2}{|c|}{ Mekan } & & \multicolumn{2}{|c|}{ Kişi } \\
\hline & $\mathrm{n}$ & Kategoriler & $\mathrm{n}$ & Kategoriler & $\mathrm{n}$ \\
\hline Her zaman & 4 & Dişarıda, Yolda & 4,2 & Arkadaş ile oynama & 8 \\
\hline Akşamüzeri & 3 & Evde, Odada & 5,3 & Akraba ile oynama & 4 \\
\hline Arkadaşlarım çağırınca & 2 & Bahçede & 3 & Yalnız oynama & 1 \\
\hline \multirow[t]{2}{*}{ Canım sıkılınca, Sabah, pazartesi } & $1,1,1$ & Okul, park, ilçe, ahır & $1,1,1,1$ & & \\
\hline & & Koridor, mutfak, salon & $1,1,1$ & & \\
\hline Toplam & 12 & Toplam & 24 & Toplam & 13 \\
\hline
\end{tabular}

Çalışma grubundaki 10 çocuğa en çok ne zaman oyun oynamayı seversin sorusu sorulmuş ve toplamda 12 görüş alınmıştır. Oyun oynamayı her zaman sevdiğini söyleyen Ç10 “öğretmenim her zaman oyunu çok seviyorum” şeklinde ifade etmiştir. Çocuklardan oyun oynadıkları yere ilişkin olarak dışarıda $(n=13)$ ve evde $(n=11)$ oyun oynadıkları görülmektedir. Çocukların cevaplara ilişkin örnekler şu şekildedir:

“Dışarda, evde, bahçede. Başka hiçbir yerde oynamak istemezdim. Çünkü başka hiçbir yer yok ki.”(Ç2)

"Benim annemgilin önünde yani bizim evin önünde bahçede. Yolda oynuyorum bahçede oynuyorum. Parkta oynuyorum.”(Ç3)

"tabiki salonda ve odada oynuyorum."(Ç5)

Ahırda oyun oynamayı sevdiğini söyleyen Ç5 "koyunların yattığı bi yer var ya orada." Olarak ifade etmiş ve resmine ( Şekil 2) aşağıda yer verilmiştir:

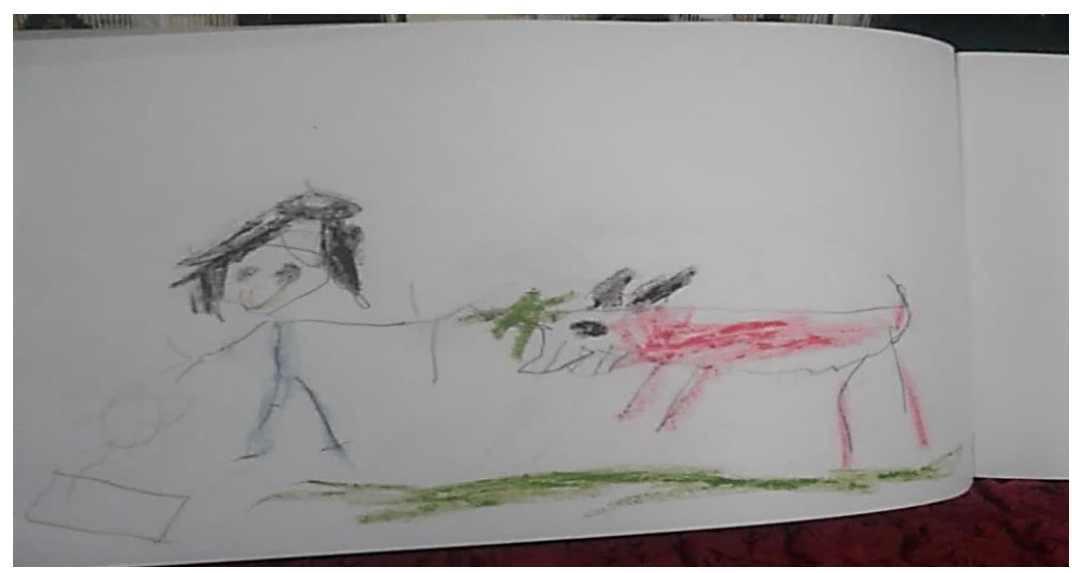

Şekil 2: Koyunu ile vakit geçirme

Çocuklara kimlerle oyun oynadığı sorulduğunda toplamda 13 cevap verildiği ve genellikle arkadaşları ile oynadıkları $(n=8)$ görülmektedir. Arkadaş temasını destekler nitelikle bir çocuğun ifadesine aşağıda yer verilmiştir:

“Süheyp ve Hüseyin onlar benim arkadaşlarım."(Ç6)

Akraba temasını destekler nitelikle iki çocuğun ifadesine aşağıda yer verilmiştir:

"Benim bi tane küçük kardeşim var iki tane kuzenim var ay ya da üç taneydi. Onlar bazen eve geliyor. Bi tanede zuzu var çok küçük bir yaş. Onlarla benim kuzenimdir onlarla ve kardeşimle evde çok oynuyorum.”(Ç4)

Arkadaş ile oynama kategorisini destekler nitelikte bir çocuğun ifadesine ve resmine (Şekil 3) aşağıda yer verilmiştir: 


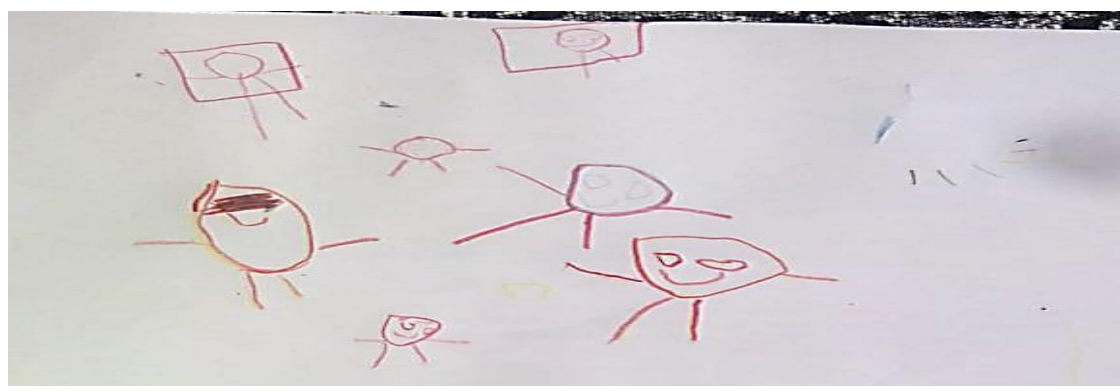

Şekil 3: Körebe ve saklambaç oyunu

'yedi kişilik, burada yedi kişilik arkadaşım yok o yüzden beş kişilik oynuyoruz. Okuluma geldiğimde yedi kişilik oynayacağım arkadaşlarımla. Körebeyi annem ve Hümeyra ile oynuyorum. Annemin işi ne zaman yoksa o zaman oynuyoruz."(Ç2).

\section{Dördüncü araştırma sorusuna ilişkin bulgular}

Çocuklara 'Okulda oynadığın oyunlar nasıl, evde oynadığın oyunlar nasıl, bir birinden farklı mı?' sorusu sorulmuş ve kategoriler ilişkin bilgilere Tablo 7’de yer verilmiştir.

Tablo 7: Çocukların evde ve okulda oynadıkları oyunların farkı

\begin{tabular}{lcc} 
Kategori & Kodlar & $\mathrm{n}$ \\
Oyunların farklı olmasının kaynağı & Oyuncak kaynaklı & 7 \\
& Arkadaş kaynaklı & 2 \\
Toplam & Öğretmen kaynaklı & 1 \\
\hline
\end{tabular}

Çocuklar kısıtlamalar sebebiyle okula gidemediklerinden dolayı okulda ve evde oynadığı oyunların farklı olup olmadığı sorulmuş ve çocuklar farklı olduğunu ifade etmişlerdir. Çocuklar bu farklılığın sebebini oyuncak kaynaklı $(\mathrm{n}=7)$, arkadaş kaynaklı $(\mathrm{n}=2)$ ve öğretmen kaynaklı $(\mathrm{n}=2)$ olduğunu ifade etmişlerdir. Öğretmenden kaynaklı farklı olduğunu açılklayan Ç8: "Farklı. Okulda bazı şeyler yasak. Okulda oynadığımız öğretmen koşmaya izin vermiyor, yerde oturmaya da izin vermiyor, saklambaç da izin vermiyor. Okulda Corona virüsünden dolayı bizim okulda oyuncağımız vardı ama şimdi artık yok. Sadece etkinlik yapıyoruz sonra böyle biz arada koşuyoruz böyle biri hırsız falan oluyor biz yakalamaya çalışıoruz oyunun adı hırsız polis." Arkadaştan kaynaklı farklı olduğunu açıklayan bir çocuğun ifadesi Ç7 ise "Okulda evcilik oyunu oynuyorduk arkadaşlarla çocukculuk hamurculuk oyunu oynuyorduk bide heykel oynuyorduk bide tren yolu oynuyorduk bide şey survivor oynuyorduk. Evde oynadığım oyunlar saklambaç yakalamaca körebe bide kutu kutu pense." Olarak ifade etmiştir. Oyuncaktan kaynaklı farklı olduğunu açıklayan bir çocuğun ifadesi ise şu şekildedir:

"Okulda oynadığım oyunlar çok güzeldi. Hani bi ara ben Kadirle oynuyorduk, öyle komikti. Siz bize şarkı açıyordunuz öyle bi oyundu okulda araba vardı. Evde arabalarımı polis yapıyorum bazı arabalarımı da hırsız yapıyorum onlar kaçıyor. Başka itfaiyem var itfaiyemle oynuyorum. Birbirinden farkh burada ki itfaiye ile okulda farkl. Okulda arabalar aynı olsa oyunlar aynı olur." (Ç2)

\section{Beşinci araştırma sorusuna ilişkin bulgular}

Çocuklara "okulların kapanmasıyla birlikte öğrendiğin yeni oyunlar oldu mu?" sorusu sorulmuş ve toplanan görüşler analiz edilerek kategoriler altında toplanmıştır. Kategorilere ilişkin bilgilere Tablo 8'de yer verilmiştir.

Tablo 8: Çocukların Öğrendiği Yeni Oyunlara İlişkin Temalar

\begin{tabular}{llc} 
Kategoriler & Kodlar & $\mathrm{n}$ \\
Hareketli oyunlar & Kovalamaca oyunu & 2 \\
& $\begin{array}{l}\text { Sandalye kapmaca, ebe oyunu, mendil } \\
\text { oyunu, kutu oyunu }\end{array}$ & $1,1,1,1$ \\
\hline Dijital oyunlar & Telefon, bilgisayar oyunları & 1,1 \\
\hline
\end{tabular}




\begin{tabular}{lll}
\hline Araçlı oyunlar & Bisiklet sürme & 1 \\
\hline Yapı inşa oyunları & Çamur oyunu & 1 \\
\hline Yeni oyun öğrenmedim & & 4 \\
\hline Toplam & 14 & \\
\hline
\end{tabular}

Tablo 8'de çocukların verdiği cevaplar 4 kategori altında toplanmıştır. Çocuklar okulların kapalı olduğu süreçte hareketli oyunlar, dijital oyunlar, araçlı oyunlar, yapı-inşa oyunlarını öğrendiklerini ifade etmişlerdir. Hareketli oyunlar temasına yönelik bir çocuğun ifadesi:

"Evet, yüksek ebe, kovalamaca, bisiklet sürme." (Ç3)

Dijital oyun temasına yönelik bir çocuğun ifadesi:

"Canım sıkıllyor tablet, bilgisayar, telefon onlar hep var onlarda oyun oynuyorum, bilgisayarda boyama tek var." (Ç1)

"Zümra diye bi arkadaşım vardı o bana sandalye kapmaca ve mendil mandal öğretti. Bide telefondaki oyunları biraz öğrendim ama yeni gelen oyunları ablam öğretiyor."(Ç8)

Dijital oyunlar kategori altında Ç8 “evde oynuyorum, bilgisayarda da oynuyorum telefonda da." Şeklindeki ifadesini şu şekilde (Şekil 4) resmetmiştir:

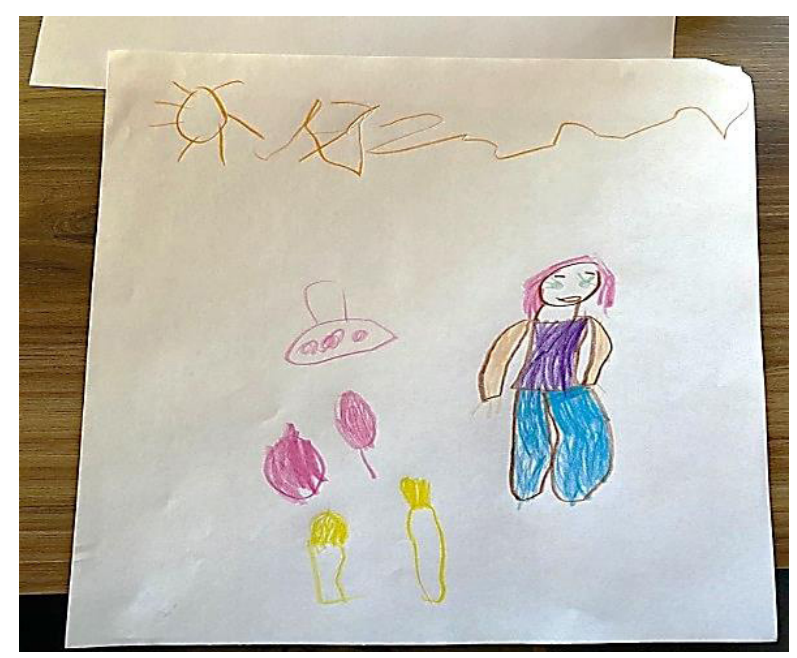

Şekil 4: Bilgisayarda bebek oyunu

\section{SONUÇ, TARTIŞMA VE ÖNERİLER}

$\mathrm{Bu}$ araştırma kapsamında köyde yaşayan altı yaş çocukların Covid-19 Pandemi sürecinde oyun yaşantıları incelenmiştir. Araştırma sonuçları incelendiğinde çocukların en çok oynadığı ve en sevdiği oyunların genellikle harekete dayalı ve araçlı oyunlardan saklambaç, yakalama, ebe oyunları ve bisiklet sürmeyi tercih ettikleri görülmüştür. Ayrıca iki çocuğun kuş ve kuzu ile vakit geçirmekten keyif aldığı ortaya çıkmıştır. Elde edilen bu bulgulardan farklı olarak Sapsağlam (2018), yapmış olduğu araştırmada 4-5 yaş arasında ki çocukların evcilik, araba, saklambaç gibi geleneksel oyunlardan çok dijital ortamda oynanan bilgisayar oyunlarını tercih ettiklerini belirtmiştir. Mevcut araştırma çocukların pandemi sürecinden kaynaklı olarak okula devam edememeleri, bu nedenle enerjilerini atmak için harekete dayalı ve araçlı oyunları tercih ettikleri aynı zamanda okullarda yüz yüze eğitime ara verildiği için arkadaş ortamlarının kısıtlanması çocukları daha çok evde bakımını üstlendikleri hayvanları ile vakit geçirmeye yönlendirdiği düşünülmektedir. Çocukların en çok sevdiği oyun çizimlerinde çocukların daha çok arkadaşları ile birlikte kalabalık bir ortamda oynanan oyunlara yer verdikleri ve evcil hayvanları ile arkadaşlık kurdukları görülmüştür. Çocuklar oyunlarını açıklarken sosyal becerilere ve arkadaşlık kavramlarına daha çok vurgu yapmaktadırlar. Benzer şekilde Durualp ve Aral (2010) oyunun çocukların sosyal gelişimlerinde ve arkadaşlık ilişkilerinde etkili olduğunu ifade etmişlerdir. Farklı olarak Mart ve Kesicioğlu (2020) pandemi sürecinde çocukların ev içerisinde aileleri ile daha çok oyun oynadıklarını kısıtlamaların ev içerisinde birlikte oyun zamanının arttığını göstermektedir. Çalışma bulgularındaki farklılı̆̆ın sebebinin mevcut çalışmada çocukların bahçe alanlarının fazla olduğu köylerde yaşamasından kaynaklı olduğu düşünülmektedir. 
Çocuklar Covid - 19 Pandemi kısıtlamalarında oyun oynarken kendilerini genellikle oyun esnasında iyi, mutlu, heyecanlı ve eğlenceli hissettiklerini ifade etmişlerdir. Ramazan ve Öveç (2017) çalışmasında çocukların mutlu olmayı oyun oynamak ile bağdaştırdığını, üzüldüklerinde ise oyun oynamayı tercih ettiklerini bulmuşlardır. Çocukların oyun ile mutlu olma duygusunu bağdaştığını; oyun oynamanın çocuklarda eğlence, sevinç ve mutluluk gibi pozitif duygular uyandırdığını (Güven, 2018) ve bireyde olumlu etki yarattığı söylemek mümkündür. Pandemi sürecinde sokağa çıkma yasaklarından dolayı oyunları kısıtlanan çocukların oyun sırasındaki duygusal durumlarının genel olarak değişmediği tüm dünyayı etki altına alan Covid-19 salgın süreci gibi negatif bir süreçte bile çocuklar için oyunun bir iyi oluş hali olduğu söylenebilir.

Çocukların oyun süreçlerinde zaman, mekan ve birlikte oyun kurdukları kişilere yönelik sonuçlara bakıldığında çocukların oyun oynamayı her zaman tercih ettikleri görülmüştür. Koçyiğit, Tuğluk ve Kök'ün (2007) de belirttiği üzere oyun, okul öncesi dönem çocuklarının fırsat buldukları her zaman yalnız veya arkadaşları ile eğlenmek veya öğrenmek için başvurdukları bir etkinliktir. O nedenle pandemi gibi sosyal hayatın ve eğitimin kısıtlandığı olağanüstü bir dönemde bile köyde yaşayan çocukların oyunlarının kısıtlanmadığı sabah, akşam, her zaman oyun oynayabildikleri görülmüştür. Çocukların oyun oynadıkları mekanlar incelendiğinde genellikle yol, bahçe, park gibi dışarı oyun alanlarına daha çok görüş bildirdikleri ayrıca ev, oda, koridor gibi ev içinde de oyun alanlarını tercih ettikleri görülmüştür. Benzer şekilde Erbay ve Durmuşoğlu Saltalı’nın (2012) çalışmasında çocukların ev içinde daha çok kendi odalarında, salon ve oturma odasında dışarıda ise çocuk parkları ve bahçelerde oynadıkları sonucunu elde etmişlerdir. Bununla birlikte Cordovil vd. (2021) öğretmenlerin Covid - 19 Pandemi sürecinde okul öncesi eğitim kurumlarında uygulanan kısıtlamalar sonucunda okula döndüklerinde çocukların materyal paylaşımının sınırlandığını öğretmenlerin dışarı oyunlarının sürelerinin arttırdıklarında çocukların daha aktif ve mutlu olduklarını gözlemlediklerini ifade etmiştir. Farklı dışarı oyun alanları çocukların gelişimleri açısından pozitif çıktılar sağladığı (Okur-Berberoğlu, 2021) ve sınıf dışı oyunların zengin öğrenme ortamlarının eğitim süreçleri kısıtlanan çocuklara yarar sağladığı düşünülmektedir.

Çocukların okulların kapanması ile birlikte en çok kimlerle oyun oynamayı sevdikleri sorulduğunda daha çok arkadaşları ile oyun oynamayı sevdiklerini ifade etmişlerdir. Çocukların çizdikleri resimlerde de genellikle arkadaşlarını ya da evcil hayvanlarını resmettiği görülmüştür. Benzer şekilde Kesicioğlu, Hacribrahimoğlu ve Aktaş (2019) çocukların oyun algılarını incelediği çalışmalarında çocukların en çok arkadaşlarını, anne-baba ve kardeşlerini resmettiklerini gözlemlemişlerdir. Okul öncesi dönem, çocuklarının arkadaşlık kurma ve arkadaşlığı sürdürme becerilerinin başladığ 1 ve sosyal becerilerinin hızla geliştiğini bir dönemdir (Arda, 2011). Çocukların oyunlarına en çok yansıttıkları kişilerin arkadaş olması çocukların birlikte olmaktan en çok hoşlandıkları kişileri resimlerine yansıttıkları göz önünde bulundurulduğunda pandemi döneminde çocukların arkadaş ortamlarına özlem duyduğu söylenebilir.

Evde oynadığı oyunlar ile okulda oynadığı oyunların değişiklik gösterip göstermediği incelendiğinde ise çocukların çoğunluğu evde ve okulda oynanan oyunların öğretmen, arkadaş ve oyuncak kaynaklı olarak birbirinden farklı olduğunu ifade etmişlerdir. Çocukların Pandemi döneminde okulların kapanması ile kısıtlı sayıda arkadaş ile oynadığı, sınıf ortamındaki çeşitli oyuncakların evde olmaması ve öğretmenlerinin oyunlarına şekil verdiği için evde ve okulda oynanan oyunların farklı olduğu cevabı alındığı düşünülmektedir. Cordovil vd. (2021) yapmış olduğu çalışmada ebeveynler, pandemi sürecinde yaşanan kısıtlamalarda çocukların pandemi öncesi sürece kıyasla daha kalitesiz öğrenme ortamlarına maruz kaldığı ve genellikle günlük aktivelerde bulunduklarını söylemişlerdir.

Çocukların okullar kapanması ile öğrendiği yeni oyunlara bakılırsa çoğunlukla hareketli oyun ve dijital oyunlar öğrendiği ve bir kısmının ise yeni oyun öğrenmediği görülmektedir. Çocukların Covid-19 pandemi sürecinde ev içinde geçirdiği vaktin artması teknolojik aletlerin daha çok kullanılmasına sebep olduğu dijital ortamda oynanan yeni oyunların öğrenildiği, yine bu süreçte yeni oyun öğrenmediğini söyleyen çocukların ise okul ortamından uzaklaştığ için yeni oyun öğrenemediği düşünülmektedir.

Araştırma sonuçları köyde yaşayan çocukların Covid-19 Pandemi sürecinin oyun yaşantılarının olumsuz etkilemediği, kaygıya sebep olmadığı onların her zaman severek oyun oynamaya devam ettiğini ancak resimlerinde arkadaş özlemi duyduklarını göstermektedir. Araştırma sonuçlarının çalışma grubundaki çocukların köyde yaşaması, bahçe gibi oyun alanlarının olması, evcil ve çiftlik hayvanlarına sahip olmaları, dışarı oyunlarında şehirlerde yaşayan çocuklara göre kısıtlamalara maruz kalmamasının etkili olduğu düşünülmektedir. Araştırmada ulaşılan sonuçlar doğrultusunda pandemi sürecinde çocukların enerjilerini atabileceği hareketli oyunlar sergileyebileceği açık alanların tercih edilmesi önemlidir. Hali hazırda okulların açılması ile birlikte öğretmenlerden yalnızlaşan çocukların etkileşimlerini artırmak adına daha çok açık hava etkinliklerin yer vermesi önerilmektedir. Ayrıca çocuklar arkadaşları 
ile oynamayı çok sevdiklerini ve çizimlerine de arkadaşlarını yansıttığı göz önünde bulundurulduğunda öğretmenlerin bireysel etkinliklerden yerine sosyalleşebilecekleri, çocukların birbiri ile daha çok iletişime geçebilecekleri etkinlikler tercih etmesi önemli görülmektedir. Bununla birlikte mevcut çalışmada çocuklar ebeveynleri ile oyun oynamadıklarını ifade etmişlerdir. Ebeveynlerin çocukları dijital oyunlara yönlendirmek yerine çocukları ile oyun oynayacak ortamlar yaratarak ebeveyn-çocuk etkileşimini arttıracak planlamalar yapabilirler. Bundan sonraki çalışmalarda Pandemi sonrası çocukların oyun süreçlerine ilişkin yaşantılarını gözlemleyen çalışmalar planlanabilir.

\section{KAYNAKÇA}

Arda, T. B. (2011). Alternatif düşünme stratejilerinin desteklenmesi programının okul öncesi çocuklarının sosyal becerileri üzerinde etkililiğinin değerlendirilmesi. Yayınlanmamış yüksek lisans tezi, Ege Üniversitesi, İzmir.

Burgaz Uskan, S. \& Bozkuş, T. (2019). Eğitimde oyunun yeri. Uluslararası Güncel Eğitim Araştırmaları Dergisi, 5(2), 123-131.

Büyüköztürk, Ş., Kılıç Çakmak, E., Akgün, Ö.E., Karadeniz, Ş. ve Demirel, F. (2014). Bilimsel araştırma yöntemleri (17. Baskı). Ankara: Pegem Yayınları

Can, E.(2020). Coronavirüs (Covid-19) pandemisi ve pedagojik yansımaları: Türkiye’de açı ve uzaktan eğitim uygulamaları. Açıöğretim Uygulamaları ve Araştırmaları Dergisi, 6(2), 11-53.

Creswell, J. W. (2013). Nitel araştırma yöntemleri (3. Baskıdan Çeviri) (Çev. Ed. M. Bütün ve S.B. Demir). Ankara: Siyasal Kitabevi.

Cordovil, R., Ribeiro, L., Moreira, M., Pombo, A., Rodrigues, L. P., Luz, C., ... \& Lopes, F. (2021). Effects of the COVID-19 pandemic on preschool children and preschools in Portugal. Journal of Physical Education and Sport, 21, 492-499.

Durualp, E. \& Aral, N. (2010). Altı yaşındaki çocukların sosyal becerilerine oyun temelli sosyal beceri eğitiminin etkisinin incelenmesi. Hacettepe Üniversitesi Eğitim Fakültesi Dergisi, 39(39), 160-172.

Erbay, F., \& Saltalı, N. D. (2020). Okul öncesi dönem çocuklarının okul hazırbulunuşluklarının yordayıcısı olarak sosyal bağımsızlık. OPUS Uluslararası Toplum Araştırmaları Dergisi, 16(31), 4138-4155. DOI: 10.26466/opus.681864.

Gülay, H. (2009). Okul öncesi dönemde akran ilişkileri. Balıesir Üniversitesi Sosyal Bilimler Enstitüsü Dergisi, 12(22), 82-93.

Güven, S. (2018). Çocukların Oyun Tercihleri Üzerine Bir Çalışma. Journal of Turkish Studies, 13(27), 795-813.

Kesicioğlu, O. S., Yıldırım-Haciibrahimoğlu, B. \& Aktaş, B. (2019). An examination of preschool aged children's perceptions of play. OPUS-International Journal of Society Researches, 11(18), 451-472. DOI: 10.26466/opus.540840.

Kızıltaş, E., Halmatov, S., \&Ertör, E. (6). 6 yaş çocukların kendileri için uygun gördükleri hayvan metaforlarının incelenmesi. Bayburt Eğitim Fakültesi Dergisi, 12(23), 399-414.

Koçyiğiit, S., Tuğluk, M. N., \& Mehmet, K. Ö. K. (2007). Çocuğun gelişim sürecinde eğitsel bir etkinlik olarak oyun. Atatürk Üniversitesi Kazım Karabekir Eğitim Fakültesi Dergisi, (16), 324-342.

Mart, M., \& Kesicioğlu, OS (2020). COVID-19 Pandemi Sürecinde Ailelerin Evde Oyun Oynamaya İlişkin Görüşleri. Elektronik Türkçe Çalışmaları, 15 (4).

Okur - Berberoğlu, E. (2021). Yapılandırılmamış Açık Hava Oyunlarının Bir Çocuk Üzerindeki Bazı Etkileri: Yeni Zelanda’dan Bir Vaka Çalışması. Uluslararası Elektronik Çevre Eğitimi Dergisi, 11 (1), 58-78.

Özer, A., Gürkan, A. C., \& Ramazanoğlu, O. (2006). Oyunun çocuk gelişimi üzerine etkileri. Furat Üniversitesi Doğu Araştırmaları Dergisi, 4(3), 54-57.

Pilten, P. ve Pilten, G. (2013). Okulla ilgili oyunlarla ilgili algılarının değerlendirilmesi. Mersin Üniversitesi Eğitim Fakültesi Dergisi, $9(2), 15-31$.

Ramazan, O. ve Öveç, Ö. (2017). 66-72 aylı çocukların sevgi, mutluluk, korku, üzüntü duygularını tanımlama durumlarının ve resmederken kullandıkları renklerin incelenmesi. Uludağ Üniversitesi Eğitim Fakültesi Dergisi, 30(1), 265-289.

Sapsağlam, Ö. (2018). Okul öncesi dönem çocuklarının değişen oyun tercihleri. Ahi Evran Üniversitesi Kirşehir Eğitim Fakültesi Dergisi, 19(1), 1122-1135.

Singer, E., Nederend, M., Penninx, L., Tajik, M., \& Boom, J. (2014) The teacher's role in supporting young children's level of play engagement, Early Child Development and Care, 184:8, 1233-1249, DOI: 10.1080/03004.430.2013.862530

Tuğrul, B., Metin-Aslan, Ö., Ertürk, H. G., \& Altınkaynak, Ş. (2014). Anaokuluna devam eden 6 yaşındaki çocuklar ile okul öncesi öğretmenlerinin oyun hakkındaki görüşlerinin incelenmesi. İnönü Üniversitesi Eğitim Fakültesi Dergisi, 15(1), 97-116.

Ünal, M. (2009). Çocuk gelişiminde oyun alanlarının yeri ve önemi. İnönü Üniversitesi Eğitim Fakültesi Dergisi, 10(2), 95-110.

Yıldırım, A. \& Şimşek, H. (2016). Sosyal bilimlerde nitel araştırma yöntemleri. Ankara: Seçkin Yayıncılık. 


\title{
Play Experiences of Six-Year-Old Children Living in a Village During the Covid-19 Pandemic
}

\author{
Aylin SOP (iD, Şeyma DEMIRGIRAN (iD)
}

\section{Introduction and purpose}

The restrictions imposed in line with the measures taken with the Covid-19 pandemic have brought a new reality to the lives of children. Children, who got deprived of education at school, the opportunity to play outdoors and spend time with their friends, were suddenly confined to their homes and faced with a homeschooling program. As a result, play behaviors which are preschool children's most important engagement have also changed. Correspondingly, children have started to play outside the school, differentiate their play environments and playmates and spend less activity-based time. With the current study, it was attempted to determine pre-school children experiences of the play during the Covid-19 pandemic.

\section{Literature Review}

Preschool education occurs in an environment where the child learns by discovering, takes an active role and his/her creativity is fostered. In this period, the child learns through play, gets to know herself/himself and his/her environment through play, expresses his/her thoughts with play, in short, play is everything for the child and is one of the most important parts of pre-school education. Although the type of play, the name of it and the tools used for it vary from culture to culture, the play will exist wherever the child is. It is seen that social skills such as social behavior and peer relations, problem solving skills and cooperation skills improve with the increase in the time spent with friends in play in the pre-school period. The development of play skills is seen as the main determining factor in the development of social skills. Although the existing research has revealed important insights about children's play experiences, no study has been found that specifically examines children's perceptions of the concept of play during the Covid-19 pandemic. For this reason, the fact that this study aims to determine the effects of an extraordinary situation such as the pandemic on the changing concept of play is considered important as it will contribute to the literature established in the field of pre-school education.

\section{Methodology}

Phenomenology, one of the qualitative research methods, was used in the study to examine the preschool children's play experiences during the Covid-19 pandemic. The data of the study were collected from 10 children in the kindergarten of a village school affiliated to the Ministry of National Education in the Gurpinar district of the city of Van in the 2020-2021 school year. In the study, a semi-structured interview form created by the researcher by taking expert opinion was used as the data collection tool. The data collected with the semi-structured interview form were also supported by the data obtained from the drawings of the children. The data obtained from the interview form, the pictures drawn by the children and the data obtained as a result of the interviews about the pictures were analyzed with the content analysis technique. 


\section{Results, conclusion and suggestions}

When the results of the study were examined, it was seen that the most frequently played and favorite plays of the children were hide-and-seek, tag and cycling, which generally require being active and tools. It can be thought that since children had to stay at home for a long time due to the pandemic, they preferred active games requiring tools so that they could dispose their energy. In addition, the restriction of their contact with their friends as schools were closed forced them to spend their time more with pets at their homes and family members.

In the drawings of the children in which they depicted the plays they like the most, they usually included games played with friends in crowded settings and their friendships with pets. The children put more emphasis on social skills and the concept of friendship while explaining their plays. It can be said that play is a state of well-being for children, even in a negative process such as the Covid-19 pandemic, which has affected the whole world and that despite lockdowns imposed because of the pandemic, the children's emotional state did not change much in general.

The results of the study show that Children's play experiences of play the Covid-19 pandemic did not change much and that they always continued to play with pleasure. It is thought that the results obtained in the current study were affected by the fact that the children participating in the study were living in a village, they had playgrounds such as gardens, had domestic and farm animals and were not exposed to restrictions in outdoor games compared to children living in cities. In light of the results of the current study, it can be said that open areas should be provided for children to play outside so that they can dispose their energy and can be active. With the opening of schools, it is suggested that teachers should include more outdoor activities for children whose movements were restricted during the pandemic. In addition, given that children love to play with their friends and depicted their friends in their drawings, teachers should prefer activities in which children can interact with each other rather than individual activities. However, in the current study, the children stated that they did not play games with their parents. Instead of directing children to digital games, parents can make plans to increase parent-child interaction by creating environments where they can play games with their children. In the studies to be conducted in the future, the changes in children's perceptions of play after the end of the pandemic can be investigated. 